\title{
The Role of the Indonesian Government in Implementing REDD (Reducing Emissions from Deforestation and forest Degradation) Program Under Former President Yudhoyono
}

\author{
Johni R.V. Korwa \\ Universitas Cenderawasih \\ Email: johnikorwa@gmail.com
}

\begin{abstract}
This paper examines the extent to which the Indonesian government has reduced its greenhouse gases emissions coming from deforestation and forest degradation by using REDD program. Such program is highly regarded as a sophisticated instrument to foster collaboration between developing and developed countries in slashing the rate of deforestation. Indonesia itself has enacted the program as a national policy since 2009 under former President Yudhoyono. In this article, the secondary research method is utilized to gather data as well as adopting a qualitative approach to analyse the topic. This paper has found that Indonesia's policy to curb the emissions from deforestation and forest degradation by conducting REDD program has not yet been successful, because of weaknesses in the implementation. They include the limitation of President's power in driving policy; the ineffective of information exchange; the inability to do Monitoring, Reporting and Verification (MRV) activities; and contradiction in the decentralization process with regards to REDD implementation. However, some achievements are identified: a slow decline in the rate of deforestation and forest degradation; the continuity partnership between Indonesia and Norway; and the more participation of local stakeholder in supporting REDD program.
\end{abstract}

Keywords: REDD, Indonesia, and policy.

Abstrak

Paper ini membahas tentang sejauh mana peran Pemerintah Indonesia dalam mengurangi dampak emisi gas rumah kaca akibat deforestasi dan degradasi hutan melalui program REDD. Program ini sebagai instrumen komprehensif untuk mendorong kolaborasi antara negara berkembang dan negaranegara maju untuk memangkas deforestasi. Indonesia telah memberlakukan program ini sejak tahun 2009 melalui Kebijakan Nasional pada Pemerintahan Susilo Bambang Yudhoyono. Penelitian ini menggunakan data sekunder dan mengadopsi pendekatan kualitatif untuk menganalisis topik tersebut. Penelitian ini menemukan bahwa kebijakan Indonesia dalam mengekang emisi gas melalui program REDD belum berhasil, karena kelemahan dalam implementasi nya yakni keterbatasan kekuasaan presiden dalam mengendalikan kebijakan; tidak efektifnya pertukaran informasi; ketidakmampuan dalam melakukan pemantauan; pelaporan dan verifikasi; dan kontradiksi desentralisasi dalam implementasi REDD. Namun beberapa capaian diantaranya: penurunan dan laju deforestasi dan degradasi hutan; kemitraan yang kontinyu antara Indonesia dan Norwegia; dan semakin banyak partisipasi pemangku kepentingan dilevel daerah untuk implementasi REDD

Kata kunci: REDD, Indonesia dan Kebijakan 


\section{Introduction}

The notion of Reducing Emission from Deforestation (RED) was the first time proposed by Papua New Guinea (PNG) and Costa Rica on behalf of the newly formed 'Coalition for Rainforest Nations' at the Conference of the Parties (COP) in Montreal in 2005 (Okereke \& Dooley 2010, p. 83). These two countries offered suggestion that developing countries which were successful in reducing their rate of deforestation significantly should be given financial incentives, such as tradable carbon credits. Subsequently, this idea was discussed and endorsed at the United Nations Framework Convention on Climate Change (UNFCC) meeting in Bali, 2007 (Dehm 2012, p. 98). The Reducing Emission from Deforestation and forest Degradation (REDD) program was eventually launched by the United Nations in 2008 (REDD 2009).

Since the launching of REDD program, Indonesia has become the first country enacting national REDD regulations in May 2009 as national policy to overcome deforestation and forest degradation (Johnstone 2010, p. 93). This is because Indonesia is responsible for releasing around $85 \%$ greenhouse gas (GHG) to the atmosphere after the United States and China (Greenpeace 2012, p. 6).
To put it differently, Indonesia can be assumed as a prime candidate among developing countries for implementing REDD program. Deforestation and forest degradation in Indonesia are mainly caused by three major land-use activities: commercial logging, timber, and oil palm plantation (Irawan, Tacconi \& Ring 2013, p. 76). These kind of activities have led to the degradation of Indonesian forest approximately 1.17 million ha each year from 2003 to 2006 (UN-REDD 2015b).

As well as committing to tackle such a problem by implementing UNREDD program, former President Yudhoyono announced Indonesia's commitment at the G-20 Summit in Pittsburgh in 2009 to reduce emissions by $26 \%$ voluntarily on its own or by $41 \%$ through international support (Brockhaus et al. 2012, p. 1). This simultaneously received response from Norway and then marked by signing a Letter of Intent (LoI) in 2010 to enter into a REDD+ partnership consisting of three phases: Phase 1 'Preparation'; Phase 2 'Transformation'; and Phase 3 'Contribution for verified emission reduction' (Greenpeace 2012, p. 7). Owing to this, President Yudhoyono formulated a range of governmental policies in order to respond that support, one of which was the establishment of the Task Force for the Preparation of a 
REDD+ Agency by issuing Presidential

Decree No. 19/2010 (Santosa, Khatarina \& Suwana 2013, p. 3).

There has been some progress identified during the implementation of REDD program in Indonesia. This paper, therefore, will examine the extent to which Indonesian government has reduced its GHG emissions coming from deforestation and forest degradation by using REDD program or, to be more precise, whether or not Indonesia is successful in implementing such a program. It argues that Indonesian's policy to lower the emissions from deforestation and forest degradation by conducting REDD program has not yet been successful, because of limitation in the implementation. This paper sets limits by only focusing on implementing the REDD program under SBY's second government (2009-2014).

This paper will first give a brief background of the nature on deforestation and forest degradation in Indonesia. It will then evaluate some progress which have been made as well as explain the reasons why the program implementation is ineffective. This paper will finally have discussion and offer several policy recommendations in order to enhance the way in which the REDD program is implemented in Indonesia for the years to come, as follows.

\section{Background: Deforestation and Forest}

\section{Degradation in Indonesia}

The issue of deforestation and forest degradation has been a worldwide problem which not only happens in Indonesia but also in other countries such as Argentina, Brazil, Bangladesh, Papua New Guinea and so forth. But what is deforestation and forest degradation? DeFries et al. (2007, p. 386) simply define deforestation as alteration from forest land to non-forest land. They maintain that although deforestation can be monitored easily, it releases a large amount of carbon stock per deforested area.

Moreover, Geist and Lambin (cited in Fry 2008, p. 168) observe that deforestation is primarily caused by several factors such as economic, institutions, infrastructure extension and wood extraction. Allen and Barnes (1985, p. 180) also argue that deforestation is mainly attributed to population growth, agricultural expansion, and high level of wood production. Forest degradation, on the other hand, is not considered as important as deforestation; yet it can act as a precursor to deforestation and significantly contribute to emissions such as overharvesting of fuel woods, unsustainable timber production, and fires at the edge of forest fragments (DeFries et al. 2007, p. 386). This issues can be found 
in many developing countries, one of which is Indonesia.

Indonesia possess tropical forest which is the third largest on Earth with an area of 97.4 Mha2, ranging from evergreen low-lying dipterocarp forests in Sumatra and Kalimantan to non-dipterocarp lowlying forests and periodic monsoon forests in Papua (Greenpeace 2012, p. 6). According to the basic forestry act no. $5 / 1967$, it is stated that all Indonesian forests are owned by country as state forest property (Siscawati 1998, p. 554). In the same way, Irawan, Tacconi and Ring (2013, p. 76) observe that under the Forestry Law 41/1999, the National Ministry of Forestry was given authority to manage 120 million hectare of state forestland which were divided into protection, production, and preservation forests.

Unfortunately, a range of productive activities legalised by the law to exploit Indonesian forests tend to lead to deforestation and forest degradation. A case in point is the activity of commercial logging. Even though this activity is allowed by the government with the compliance to perform selective timbercutting for around 20 years, it has been found that such activity failed to meet the obligation thereby deforestation and forest degradations seems inevitable (Irawan, Tacconi \& Ring 2013, p. 76).

Apart from the commercial logging, the Indonesian government also legalises the activity of logging in natural forests for the purpose of generating revenues and employment. It has caused severe forest degradation which was later handed over to a state-owned company for rehabilitation. Having said that, the rehabilitation policies apparently allow the company to convert severely degraded forests to commercial timber plantation such as acacia, thus avoiding forest degradation seems impossible. The forestry law also gives permission to the use of land for agriculture, tree crop plantation like oil palm, and mining, all of which are indirectly decreasing the ability of forests (Irawan, Tacconi \& Ring 2013, p. 76).

As a consequence, Indonesia became the second largest annual net loss of forest area (-1914, 1000 ha/year) after Brazil (-2890, 1000 ha/year) between 1990 and 2000 (FAO 2010, p. 21). Indonesia's forest degradation is estimated around 1.17 million ha of forest from 2003 to 2006 (UN-REDD 2015b). By enacting UNREDD program, therefore, is expected to assist Indonesia to overcome deforestation and forest degradation. Even so, it has been found that the program is having 
trouble in the scope of implementation; yet some achievements have been underlined in this paper, for the following reasons.

\section{The achievements identified during the implementation of REDD}

It could be argued that deforestation and forest degradation in Indonesia have reduced since the implementation of REDD. Indeed, this can be seen in the declaration of Indonesian Ministry Forestry stating the rate of deforestation had declined by 0.45 million ha/year between 2009 and 2011 (Santosa, Khatarina \& Suwana 2013, p. 1). The World Resources Institute (WRI) also showed a slow declined in the average of Indonesia tree-cover loss around 1.6 million hectares yearly between 2011 and 2013. Likewise, a study found Indonesia's primary forest loss slowed from 2011to 2013, just below one million hectares per year which was the lowest in a decade (Parlina 2015). Nonetheless, a study using high-resolution global maps of $21^{\text {st }}$ century found that Indonesia was a country whose the biggest increase in forest loss (1021 km2/year) in comparison with other countries globally, with a low of under $10,000 \mathrm{~km} 2 /$ year from 2000 to 2003 and a high of over 20,000 km2/year between 2011 and 2012 (Hansen et al. 2013, p. 850).
It has also been argued that Indonesia successfully maintains its relationship with Norway which is a partner for Indonesia in REDD context. According to IndonesiaNorway REDD+ partnership first evaluation, it is stated that this partnership has not only successfully offered benefits for national circumstances and the fate of Indonesian people and ecosystems, but also produced capacity to deliver quantified and verified carbon mitigation based on a market-standard (Caldecott et al. 2011, p. 28).

Moreover, the Indonesian new President Joko Widodo and Norwegian Prime Minister Erna Solberg also agree to continue the REDD+ partnership cooperation during a bilateral meeting between two countries in Jakarta in 2015 (Parlina 2015). However, a controversial policy has currently been found under the Presidential decree No. 16, 2015 which states that the REDD+ Agency will report to the Minister for Environment and Forestry. This is clearly inconsistent with the Letter of Intent signed by Norway and Indonesia in 2010 stating that, "Establish a special agency reporting directly to the President to coordinate the efforts pertaining to the development and implementation of REDD+ (Lang 2015a). 
Last but not least, REDD program has been successful in raising awareness of Indonesian people to stand together to overcome deforestation and forest degradation in Indonesia. Indeed, Angelsen and Brockhaus (2009, p. 113) maintain that all stakeholders such as local officers, district and national government organizations, investors and local people should come into play to ensure the policy implementation of REDD program. Without the involvement of those actors, the program may not be successful; a case in point is in Central Sulawesi. At there, there is announcement of commitment of stakeholders, particularly the religious leaders to support the REDD program by making declaration on the reduction of emissions. As well as religious leader commitment, there is also governor decree selecting five districts for developing REDD+ demonstration activities (UNREDD 2015a).

The decree is expected to strengthen the successful implementation of REDD program because without such support the program may count for nothing. Yet, it must be admitted that the achievement made in Central Sulawesi in which the religious leaders support the REDD program may be rare to be found in other regions across Indonesia.
The weaknesses of REDD program identified during the implementation

The first weakness identified is that the political context in Indonesia limits the power of President to produce any reform process of REDD program. Such reform itself requires strong political support because it will have potential impact on the winners and losers in the Indonesian economy (Luttrell et al. 2014, p. 73). Whilst the establishment of REDD is attributed to strong presidential backing, their relations may not sufficiently work for REDD implementation without the endorsement of pivotal actors such as the parliament and the bureaucracy (Luttrell et al. 2014, p. 73).

Since the end of President Suharto regime, Indonesia has changed its political context by the first and second amendments to the constitution in which the parliament is considered as an independent power centre. It is stated that, 'any president wishing to implement his own policies has needed to obtain approval in the form of parliamentary legislation' (Luttrell et al. 2014, p. 69).

To put it in another way, the President's executive power has been watered down by the parliament. It has also been found that the nature of coalition politics in Indonesia undermines the ability of Indonesian President to implement 
reforms (Luttrell et al. 2014, p. 73). Second, there is ineffective communication which is widely believed to weaken the successful implementation of REDD program. As argued by Moeliono et al. (2014, p. 9), the collaboration between institutional inertia and range of different information sources had limited the information exchange between transnational institutions, national government, and national society. They believe that REDD+ policy-making can be characterized by considerable public consultation among those important actors, thus making communication seems important. In the same way, Indarto et al. study in 2012 (cited in Moeliono et al. 2014, p. 9) observed that there may be no strong dialogue between discourse coalitions to produce the meaningful information exchange; it tended to have one-way communication only for public consultation in terms of implementing REDD.

Clearly, information exchange needs to be improved to support REDD. Modelling information exchange between organizations is not only purposed to assist the effectively implementation of REDD, but also to identify particular factors related to wicked problems for specific groups (Moeliono et al. 2014, p. 9).
Another weakness identified is that Monitoring, Reporting and Verification (MRV) of REDD program is still weak in which Indonesia lacks of political will and up-to-date, harmonisation and centralisation of spatial data on land uses, such as forestry, mining, agriculture concessions, conservancy areas and zone of economic development (Greenpeace 2012, p. 17). The establishment of MRV was supported by Norway during the first phase in which Indonesia received US\$1 billion for both the readiness and the implementation phases of REDD (Dermawan et al. 2011, p. 3).

MRV is purposed to determine whether or not a country has reached significant and credible reductions in emissions from deforestation and forest degradation involving data collection, estimating emission reduction and assessing information according to IPCC methodologies (Ardiansyah 2009, p. 11).

Unfortunately, it has been examined that this system is yet to meet the expectations. For example, there is a multiagency initiative (INCAS) proposing methods for national carbon accounting based on IPCC requirements in Kapuas district (a REDD+ model district in Indonesia) located in Central Kalimantan. In doing so, it is having trouble to 
centralise data housed in various agencies (Greenpeace 2012, p. 17).

Finally, there is also contradiction and uncertainty in the decentralization process of REDD+ planning and implementation in Indonesia. It has been found that local autonomy perceives itself not to attribute to levels of government. As a consequence, many higher level policies and laws tend to conflict with local regulations (Greenpeace 2012, p. 16). Irawan and Tacconi (2009) observe that policy conflicts may happen when one particular group considers a policy as relevant with its interests while others reject it. Moreover, many also argue that weak local governments tend to create non-transparent decision making process, numbers of corruption involving local leaders, poor law enforcement, and ineffective accountability mechanisms (Greenpeace 2012, p. 16)

- These problems should be improved because the sub-national level also plays a pivotal role in ensuring the successful implementation of REDD (Irawan \& Tacconi 2009, p. 436). Therefore, the collaboration between local and central government in the context of decentralization process is considerably needed in order to fortify the implementation of REDD in Indonesia.

\section{Discussions and Policy recommendation} to enhance REDD program in Indonesia

The launching of REDD program as policy instrument to overcome the issue of deforestation and forest degradation has globally promoted new innovation to approach environmental problem in this $21^{\text {st }}$ century. REDD program itself is highly regarded as one of Market Based Instruments (MBIs) approach. Stavins (2003, p. 358) defines MBIs as policy instruments which encourage character through market roles rather than through the use of method or control.

He further explains that if this instrument is well-implemented, it will encourage firms or individuals to take responsibility on their own to achieve the goals of this instrument. The REDD program is not only enacted by Indonesia, but also other developing countries across Asia-Pacific, Africa, the Caribbean, and Latin America (UN-REDD 2015c). Yet, the most important thing here is to scrutinize the extent to which this program has been implemented, particularly in Indonesia.

In the context of implementing REDD in Indonesia, MBIs is believed as the best approach in comparison with regulatory one. Indeed, Pirard (2012, p. 59) states that the use of MBIs to approach environmental goals is better than using 
the regulation method. Perhaps this is because MBIs offer incentives which encourage certain behaviour to seriously consider environmental issue and this may not be found in any approach including regulatory one. As previously discussed, the implementation of REDD in Indonesia tend not to be effective as many expected due to some weaknesses, one of which is the inaccuracy of the rate of deforestation data. While Indonesia announces its success in reducing the pace of deforestation and forest degradation, other study find it otherwise thereby making this data seems controversial. Even REDD monitor finds that Indonesia's rate of deforestation has doubled to about two million hectares per year from 2011 to 2012 which contradicts with data published by Indonesian Ministry Forestry (Lang 2015b). Indeed, there is an increase in the rate of deforestation in Indonesia every year under former President Yudhoyono; perhaps a study below can show it.

Annual primary forest cover loss in Indonesia related to deforestation. (Margono et al. 2014, p. 732)

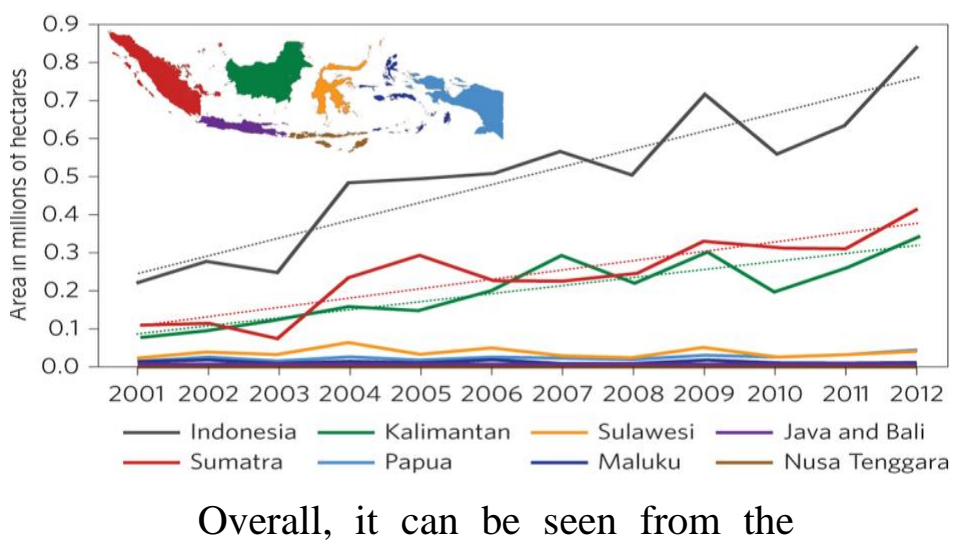

chart that the rate of deforestation marked by primary forest cover loss in Indonesia was increasing from just over 0.2 million per hectare in 2001 to just below 0.6 million per hectare in 2007 and continued to increase by approximately 0.8 million per hectare in 2012. Regarding the islands, two major regions: Sumatra and Kalimantan showed a gradual increase over the period shown. The rate of deforestation in Sumatra increased slowly from 0.1 million per hectare in 2011 to 0.4 million per hectare in 2012 albeit a dip was shown in 2003, while Kalimantan's started from just below 0.1 million per hectare to more than 0.3 million per hectare in 2012 .

The rate of deforestation in other regions such as Papua, Sulawesi, Maluku, Jawa and Bali, Nusa Tenggara remained reasonably steady (below 0.1 million per hectare) over the period shown between 2001 and 2012. In short, it is clear that the rate of deforestation in Indonesia still remained high in spite of implementing REDD program since 2009. 
According to the explanations above and considering some weaknesses identified previously, several policy recommendations are offered in this paper in order to improve the way in which REDD program works in Indonesia for the years to come. Firstly, there should be an amendment in Indonesian constitution in which it open certain avenues for President to take more power in the government. If the President has more power than the parliament, it may be effective for driving policy toward the implementation of REDD program. This is because policy formulated by President would be simultaneously implemented without the approval from the parliament. As previously discussed, every President policies need the parliament's approval, thereby making policy toward REDD seems difficult and ineffective. Even though some may argue that it would be hard to conduct amendment to give power back to the President, this paper maintains that such amendment would ensure the effectively implementation of REDD.

Secondly, the flow of communication between transnational institutions, national government, and national society should be as effective as possible or, to be more precise, there should not be limitations for the information exchange. This can be achieved by ensuring transparency and credibility in sharing information across those institutions. Moreover, information sources which will be used, should be as accurate as possible thereby avoiding controversy data information.

Thirdly, Indonesia should also enhance its political will towards the implementation of REDD as well as increase the capacity of institutions or people to gather the information data. In the context of political will, all stakeholders involving in the implementation of REDD such as local government, NGOs, party politics, private sector, international players and civil society should show their willingness and commitment to advance the way REDD is implemented. As well as improving political will, organizations or people who are responsible to do Monitoring, Reporting, and Verification (MRV) should also increase their ability. This can be achieved by encouraging them to undergo trainings or courses related to MRV.

Finally, Indonesia should strengthen the effectiveness of decentralization power in order to produce good outcomes and flow the regulations from central to local government in order to achieve the successful implementation of REDD program. The most important 
change needed in decentralization is to harmonize the relations between local and central government. In doing so, both government should conduct a regular meeting and have similar understanding about the policies and roles in the context of REDD. Another change is to improve the way local government perceive the central government. The local should consider the central as one unity of government, thus the effectiveness of decentralization can be achieved.

\section{Conclusion}

The enacting REDD program in Indonesia should be highly appreciated as the model response to tackle deforestation and forest degradation albeit some obstacles are faced. REDD program is a product of Market Based Instrument (MBIs) which may effectively advance the way countries deal with such issues. In Indonesia, unfortunately, even though this program has been implemented since 2009 , it is yet successful in the scope of implementation so far. It is because several weaknesses occur during the implementation: the limitation of President's power in driving policy; the ineffective of information exchange; the inability to do Monitoring, Reporting and Verification (MRV) activities; and contradiction in the decentralization process with regards to REDD implementation. Nevertheless, three achievements are identified: a slow decline in the rate of deforestation and forest degradation; the continuity partnership between Indonesia and Norway; and the more participation of local stakeholder in supporting REDD program. If Indonesia enables to minimize such weaknesses and maintains such achievements, it is believed that Indonesia's target to reduce GHG emissions coming from deforestation and forest degradation may come true in the near future.

In doing so, it definitely needs some improvements in the way the REDD program works for the years to come. Hence, several recommendations have been proposed in this paper: amendment in Indonesia constitutions; effective flow in the information exchange; the improvement of political will as well as the increasing capacity to gather data information; and the strengthening of decentralization power. If all these recommendations are well-implemented, the implementation of REDD program in Indonesia may be effective as many might expect. But the most important thing here is to make sure that the policies made by decision-maker like President are effectively implemented and the 
effectiveness of decentralization process is flowing well.

These two things may increase state's capacity in the context of Indonesian government to effectively implement REDD program as national policy. In addition, the continuities partnership with Norway should be maintained as well. No one can deny that Indonesia, as a developing country, still needs help from other country to work together in solving the issue of deforestation and forest degradation.

\section{References}

Allen, JC \& Barnes, DF 1985, 'The causes of deforestation in developing countries', Annals of the association of American Geographers, vol. 75, no. 2, pp. 163-84.

Angelsen, A \& Brockhaus, M 2009, Realising REDD+: National strategy and policy options, CIFOR.

Ardiansyah, F 2009, National Institutional Arrangements for REDD Case Study - Indonesia, 7, WWF-Indonesia.

Brockhaus, M, Obidzinski, K, Dermawan, A, Laumonier, Y \& Luttrell, C 2012, 'An overview of forest and land allocation policies in Indonesia: Is the current framework sufficient to meet the needs of REDD+?', Forest policy and economics, vol. 18, pp. 30-7.

Caldecott, J, Indrawan, M, Rinne, P \& Halonen, M 2011, IndonesiaNorway REDD+ Partnership: first evaluation of deliverables.

DeFries, R, Achard, F, Brown, S, Herold, M, Murdiyarso, D, Schlamadinger, B \& de Souza, C 2007, 'Earth observations for estimating greenhouse gas emissions from deforestation in developing countries', Environmental science \& policy, vol. 10, no. 4, pp. 385-94.

Dehm, J 2012, "REDD faces all around': Implementing reducing emissions from deforestation and forest degradation in Indonesia', LocalGlobal: Identity, Security, Community, vol. 10, pp. 98-125.

Dermawan, A, Petkova, E, Sinaga, A, Muhajir, M \& Indriatmoko, Y 2011, Preventing the Risks of Corruption in REDD+ in Indonesia, CIFOR.

FAO 2010, 'Global Forest Resouces Assessment ', pp. 1-340.

Fry, I 2008, 'Reducing emissions from deforestation and forest degradation: opportunities and pitfalls in developing a new legal regime', Review of European Community \& International Environmental Law, vol. 17 , no. 2 , pp. 166-82. 
Greenpeace 2012, The Indonesia - Norway Agreement to reduce greenhouse gas emissions from deforestation and forest degradation Greenpeace Assessment of Progress, retrieved from

<http://www.greenpeace.org/seasia/i d/PageFiles/469161/Full\%20Report. pdf>.

Hansen, MC, Potapov, PV, Moore, R, Hancher, M, Turubanova, S, Tyukavina, A, Thau, D, Stehman, S, Goetz, S \& Loveland, T 2013, 'Highresolution global maps of $21 \mathrm{st}-$ century forest cover change', science, vol. 342 , no. 6160 , pp. 850-3.

Irawan, S \& Tacconi, L 2009, 'Reducing emissions from deforestation and forest degradation (REDD) and decentralized forest management', International Forestry Review, vol. 11, no. 4, pp. 427-38.

Irawan, S, Tacconi, L \& Ring, I 2013, 'Stakeholders' incentives for land-use change and REDD+: The case of Indonesia', Ecological Economics, vol. 87 , pp. 75-83.

Johnstone, N 2010, 'Indonesia in the REDD: Climate Change, Indigenous Peoples and Global Legal Pluralism', APLPJ, vol. 12, p. 93.

Lang, C 2015a, Indonesia's decision to put the REDD+ Agency in the Ministry of Environment and Forestry is "not in accordance" with Norway's US\$1 billion REDD deal, REDD Monitor, retrieved from <http://www.reddmonitor.org/>.

2015b, Indonesia's rate of deforestation has doubled under the moratorium, retrieved from $<$ http://www.reddmonitor.org/2013/12/11/indonesias$\underline{\text { rate-of-deforestation-has-doubled- }}$ under-the-moratorium/ $>$.

Luttrell, C, Resosudarmo, IAP, Muharrom, E, Brockhaus, $\mathrm{M}$ \& Seymour, F 2014, 'The political context of REDD+ in Indonesia: constituencies for change', Environmental science \& policy, vol. 35, pp. 67-75.

Margono, BA, Potapov, PV, Turubanova, S, Stolle, F \& Hansen, MC 2014, 'Primary forest cover loss in Indonesia over 2000-2012', Nature Climate Change.

Moeliono, M, Gallemore, C, Santoso, L, Brockhaus, M \& Di Gregorio, M 2014, 'Information networks and power: confronting the" wicked problem" of REDD+ in Indonesia', Ecology and Society: a journal of integrative science for resilience and sustainability, vol. 19, no. 2, p. 9.

Okereke, C \& Dooley, K 2010, 'Principles of justice in proposals and policy 
approaches to avoided deforestation: towards a post-Kyoto climate agreement', Global Environmental Change, vol. 20, no. 1, pp. 82-95.

Parlina, I 2015, RI-Norway agree to continue REDD+, The Jakarta Post, retrieved from <http://www.thejakartapost.com/new s/2015/04/15/ri-norway-agreecontinue-redd.html>.

Pirard, R 2012, 'Market-based instruments for biodiversity and ecosystem services: A lexicon', Environmental science \& policy, vol. 19, pp. 59-68.

REDD, U 2009, UN-REDD Programme, retrieved from <http://www.unep.org/forests/REDD /tabid/7189/Default.aspx> .

Santosa, MA, Khatarina, J \& Suwana, AS 2013, 'The progress on governing REDD+ in Indonesia', International Journal of Rural Law and Policy, pp. 1-17.

Siscawati, M 1998, 'Underlying causes of deforestation and forest degradation in Indonesia: A case study on forest fire', in the Proceedings of IGES International Workshop on Forest Conservation Strategies for the Asia and Pacific Region, pp. 44-57.

Stavins, RN 2003, 'Experience with market-based environmental policy instruments', Handbook of environmental economics, vol. 1, pp. 355-435.

UN-REDD 2015a, Key results and achievements - Programme in Indonesia, retrieved from <http://www.unredd.org/Key_results_achievements Indonesia>. 2015b, UN-REDD in Indonesia, retrieved from <http://www.unredd.org/CountryActions/Indonesia/t abid/987/language/en$\underline{\text { US/Default.aspx }>\text {. }}$ 2015c, UN-REDD Programme Regions and Partner Countries, retrieved from <http://www.unredd.org/partner_countries/tabid/102 663/default.aspx>. 